THE AMERICAS

$66: 3 /$ January $2010 / 353.377$

COPYRIGHT BY THE ACADEMY OF

AMERICAN FRANCISCAN HISTORY

\title{
The Tales of Two Cultures: Ecclesiastical Texts and Nahua and Maya Catholicisms
}

[Priests should use] . . . an abbreviated catechism, scrupulously extracted from the Roman one so that the faithful receive the pure and sound Doctrine of the Church with uniformity and with the authority accordant to the Provincial Council . . therefore, with luck, random works destitute of legitimate authority and revision in matters so grave will not circulate such important material.

-IV Mexican Provincial Council (1771) ${ }^{1}$

W

hen in the late eighteenth century the prelates of the Fourth Mexican Provincial Council ordered all clergy to strictly employ their newly printed catechism, they provided a valuable description of the colonial Church and its relationship to unofficial ecclesiastical texts. The Fourth Provincial Council's call for the faithful to receive the doctrines of the Church in a sanctioned and uniform manner acknowledged the presence of a variety of Catholic discourses that stemmed from colonial religious works deemed to be "destitute of legitimate authority and revision." Such unofficial ecclesiastical texts avoided the editing process that both the clergy and Crown established to ensure the orthodoxy of all printed religious material. In so doing, the texts could convey diverse, unorthodox interpretations of Catholicism. These unofficial ecclesiastical texts, and the role they played in producing multiple versions of Catholicism, constitute the focus of this study.

Our understanding of Mesoamerican Catholicism has evolved much since 1933 when Robert Ricard published his Conquête Spirituelle de Mexique in which he argued that an orthodox Catholicism successfully dominated the indigenous cultures of New Spain. Over the years, scholars have refuted his argument, contest-

I thank Elizabeth Gano Sørenssen for allowing me access to the Nahuatl sermon. I also thank Matthew Restall and Rebecca Horn for their comments, and James Lockhart for his crucial aid with the transcription and translation of the Nahuatl text, and for his insights. Of course, any errors or misunderstandings are my own.

1. Catecismo y suma de la doctrina Christiana (México: Imprenta de la Bibliotheca Mexicana, 1771); translation mine. 
ing the monolithic nature of Catholicism to make room for variations and interpretations that oftentimes pushed the limits of orthodoxy. ${ }^{2}$ In the process of examining and reexamining "the Spiritual Conquest," this diverse historiography began to recognize the role of native-language religious texts in illustrating the emergence of a variety of interpretations and versions of Catholicism throughout the colonial period.

Leading the way, Louise Burkhart's The Slippery Earth greatly contributed to the recognition of how Christian moral dialogue in Nahuatl religious texts became indigenous, and sometimes unorthodox, through its translation into and use of Nahuatl rhetoric. ${ }^{3}$ Yet Christian concepts "lost in translation" were not the only contributors to colonial Catholicism's unorthodox diversity. Sometimes the Catholic doctrine ecclesiastical texts delivered to natives was simply incorrect. Indeed, the Nahuatl Theater project that examines a number of Nahuatl religious plays illustrates how at times native playwrights took great liberties with events in Christian history and even doctrine to increase their appeal and familiarity to a Nahua audience, even if such liberties "bordered on the sacrilegious."

However, despite these and scant other examples, few studies revising "the Spiritual Conquest" take advantage of indigenous-language ecclesiastical texts to analyze their specific contributions in constructing the official and unofficial Catholic doctrine natives received and, by extension, their influence on the multiple versions of Catholicism that emerged throughout the colonial period. Fewer still are studies examining ecclesiastical texts other than religious plays. ${ }^{5}$ What are these ecclesi-

2. For a few examples of works challenging the tenets of Robert Ricard's, The Spiritual Conquest of Mexico: An Essay on the Apostolate and the Evangelizing Methods of the Mendicant Orders in New Spain: 1523-72, translated by Lesley Byrd Simpson (Berkeley and Los Angeles: University of California Press, 1966), see William Madsen, The Virgin's Children: Life in an Aztec Village Today (Austin: University of Texas Press, 1960); Charles Gibson, The Aztecs Under Spanish Rule: A History of the Indians of the Valley of Mexico 1519-1810 (Stanford: Stanford University Press, 1964); Miguel León-Portilla, "Testimonios nahuas sobre la conquista espiritual," Estudios de cultural nábuatl 21 (1974), pp. 11-36; James Lockhart, The Nahuas After the Conquest: $A$ Social and Cultural History of the Indians of Central Mexico, Sixteenth Through Eighteenth Centuries (Stanford: Stanford University Press, 1992). Recently, scholars have produced cxcellent edited volumes on the topic. See Martin Austin Nesvig, ed., Local Religion in Colonial Mexico (Albuquerque: University of New Mexico Press, 2006); Susan Schroeder and Stafford Poole, eds., Religion in New Spain (Albuquerque: University of New Mexico Press, 2007).

3. Louise Burkhart, The Slippery Earth: Nahua-Christian Moral Dialogue in Sixtecnth-Century Mexico (Tucson: University of Arizona Press, 1989).

4. Stafford Poole, C.M., "Introduction: The Virgin of Guadalupe in Two Nahuatl Dramas," in Nahuatl Theater, vol. 2, Our Lady of Guadalupe, ed. Barry D. Sell, Louise M. Burkhart, and Stafford Poole (Norman: University of Oklahoma Press, 2006), p. 14. For more on Nahuatl plays see Fernando Horcasitas, El teatro nábuatl: épocas novohispana y moderna (México: Universidad Nacional Autónoma de México, 1974); Louise Burkhart, Holy Wednesday: A Nahua Drama from Early Colonial Mexico (Philadelphia: University of Pennsylvania Press, 1996); Louise Burkhart, Before Guadalupe: The Virgin Mary in Early Colonial Nahuatl Literature (Austin: University of Texas Press, 2001); and the Nahuatl Theater series from University of Oklahoma Press.

5. Some exceptions would be Burkhart, Before Guadalupe; Burkhart, The Slippery Earth; Susanne Klaus, Uprooted Christianity: The Preaching of the Christian Doctrine in Mexico Based on Franciscan Sermons of the 16th Century Written in Nahuatl, Bonner Amerikanistische Studien, no. 33, (Bonn: Anton Saurwein, 1999); don Bartolomé de Alva, A Guide 
astical texts "destitute of legitimate authority and revision" that the Fourth Provincial Council references? And how did they alter the official Catholic message intended for natives? Addressing these issues, this article employs two unofficial religious texts, a Nahuatl sermon on the conversion of Paul and a Yucatec Maya text relating the creation of Adam, to explore both the impact of unofficial ecclesiastical texts and their authors on the versions of Catholicism natives received, and the possibility for these versions to be unorthodox.

Moreover, this article uses these two tales to demonstrate how the Catholic message for the Nahuas was not the same as the one for the Mayas. A large portion of the indigenous-language ecclesiastical texts known today concern the Nahuas of Central Mexico. Due to the availability and scholarly awareness of these Nahuatl texts, the historiography reexamining "the Spiritual Conquest" has focused primarily on Central Mexico. In contrast, the paucity of known ecclesiastical Maya texts has thus far largely discouraged similar studies for the Yucatan. ${ }^{6}$ This imbalance unintentionally risks the formation of a Central Mexican model of Catholicism that encompasses all of Mesoamerica, and illustrates the need for comparative studies using the ecclesiastical texts from the various regions, cultures, and languages of Mesoamerica. Responding to this need, this article forms part of a larger dissertation project that employs Nahuatl and Maya ecclesiastical texts to examine the emergence of various locally- and culturally-tailored Nahua and Maya Catholicisms. Indeed, although the colonial Church in Central Mexico and the Yucatan shared many general characteristics, nuances between Nahua and Maya beliefs, locales, and colonial situations created branches of Catholicism individually tailored to fit the specific circumstances of each culture and region.

I begin by discussing the production of ecclesiastical texts, their authors, and goals to illustrate how unofficial, unorthodox texts emerged in a colonial society intent on religious purity and uniformity. I then examine the Nahua sermon on the conversion of Paul and the Maya account of the creation of Adam to analyze how pre-

to Confession Large and Small in the Mexican Language, 1634, ed. Barry D. Sell, John Frederick Schwaller, with Lu Ann Homza (Norman: University of Oklahoma Press, 1999); Barry Sell, "Friars, Nahuas, and Books: Language and Expression in Colonial Nahuatl Publications" (Ph.D. diss., University of California, Los Angeles, 1993); Barry D. Sell, Nabua Confraternities in Early Colonial Mexico: The 1552 Ordinances of Fray Alonso de Molina, OFM (Berkcley: Academy of American Franciscan History, 2002); David Tavárez, "Naming the Triniry: From Ideologies of Translation to Dialectics of Reception in Colonial Nahua Texts, 1547-1771," Colonial Latin American Review 9:1 (2000); John F. Schwaller, "The Ilhuica of the Nahua: Is Heaven Just a Place?" The Americas 62:3 (2006). Also, to some extent, Viviana Diaz Balsera, The Pyramid Under the Cross: Franciscan Discourses of Evangelization and the Nabua Christian Subject in Sixteenth-Century Mexico (Tucson: University of Arizona Press, 2005); and Osvaldo F. Pardo, The Origins of Mexican Catholicism: Nahua Rituals and Christian Sacraments in Sixteenth-Century Mexico (Michigan: University of Michigan Press, 2004).

6. The work of William Hanks provides notable exceptions. See his "Authenticity and Ambivalence in the Text: A Colonial Maya Case," American Ethnologist 13:4 (1986); and his "Discourse Genres in a Theory of Practice," American Ethnologist 14:4 (1987). 
existing cultural preferences altered their Catholic messages to include unorthodox doctrine that contributed to culturally-specific interpretations of Catholicism. In the end, both tales illustrate the presence of unofficial Catholic discourses that created various interpretations and versions of colonial Catholicism shaped by the diverse cultures of Mesoamerica. Apparently, the Fourth Provincial Council had reason to be concerned.

\section{Ecclesiastical TeXTS AND THEIR AUTHORS}

Ecclesiastical texts were didactic in nature providing clerics with the means of knowing how to preach Catholicism in the vernacular, and natives with the opportunity to receive the Christian message in their own languages. The task of translating Catholic concepts into indigenous languages void of many such beliefs was, no doubt, daunting. First, the Spanish clergy needed to learn the indigenous languages-a task at which only a few were truly successful. For example, Andrés Mexía seems to have struggled with Yucatec Maya as his indigenous parishioners of Xecpedz complained that he said the masses "in a twisted fashion."7 Moreover, in the introduction to his Nahuatl/Spanish large confessional manual, fray Alonso de Molina, widely praised for his linguistic abilities, himself admitted the "obscurity and difficulty of the language of these natives whose manner of speaking is very different in many ways from our Castilian language and Latin."8 And when trying to make sense of the Nahuatl phrases concerning precontact religion, the priest Hernando Ruiz de Alarcón lamented that "the language . . . is nothing but a continuous use of metaphors."

After learning the languages, ecclesiastics then faced the task of translating Christian concepts into indigenous vocabularies lacking exact parallels. To overcome such difficulties, friars enlisted native aides trained in alphabetic writing and Christian doctrine. Such aides played a key role in the composition of indigenous-language religious texts. From the 1540 s to $1578-79$, fray Bernardino de Sahagún worked with a team of Nahua writers and informants to produce a survey of precontact Nahua civilization in twelve books known today as the Florentine Codex. To compose his Coloquios y Doctrina Cristiana in the 1560s, Sahagún similarly employed Nahua elders and aides, among whom he names Antonio Valeriano, Alonso

7. Matthew Restall, "The Telling of Tales: A Spanish Priest and His Maya Parishioners," in Colonial Lives, ed. Richard Boyer and Geoffrey Spurling (New York: Oxford University Press, 2000), p. 24.

8. Fray Alonso de Molina, Confesionario mayor en la lengua mexicana y castellana (1569), with an introduction by Roberto Moreno (México: Instituto de Investigaciones Filológicas, Instituto de Investigaciones Históricas, Universidad Nacional Autónoma de México, 1984), f. 2r; translation mine.

9. Hernando Ruiz de Alarcón, Treatise on the Heathen Superstitions That Today Live Among the Indians Native to This New Spain, 1629 trans. and ed. J. Richard Andrews and Ross Hassig (Norman: University of Oklahoma Press, 1984), p. 40 . 
Bejarano, Martín Jacobita, and Andrés Leonardo. ${ }^{10}$ Indigenous aides also certainly contributed to Molina's sixteenth-century works. Although Molina fails to mention his aides, fray Juan Bautista, a fellow author of Nahuad texts in the late sixteenth and early seventeenth centuries, claims that the indigenous aide Hernando de Ribas, who also greatly contributed to Sahagún's Florentine Codex, helped compose Molina's grammar and dictionary. ${ }^{11}$

Aside from their occasional mention in the texts themselves, frequent misspellings of Spanish loanwords, indigenous tropes, and above all the influence of precontact rhetoric and culture on ecclesiastical terms all betray the hands of indigenous aides. When translating Christianity into Nahuatl or Maya, native aides commonly relied on preexisting concepts or terms. For example, Nahuas usurped the epithets from a variety of deities-Tezcatlipoca in particular ${ }^{12}$ - to translate the Catholic god as ipalnemobuani, "the giver of life," tloque nahuaqe, "possessor of the near or close," ilhuicahua tlalticpaque, "possessor of earth and heaven," tlachibualeh, "possessor of that which is created," and teyocoyani, "creator of people."13 Similarly, the Maya employed a precontact epithet for Hunab Itzamna to translate the Catholic god as ah chaabtah, "he who generates, creates." 14 Thus, indigenous aides could employ preexisting Nahuatl and Maya terms to make sense of the unfamiliar in familiar terms.

However, when no preexisting Nahuatl or Maya term adequately expressed a Catholic concept or practice, indigenous aides created one that described the appearance, manner of action, interaction, or function of the Catholic concept, thus creating vocabularies composed of descriptive nouns and verbs. In one case regarding the sacrament of baptism, Nahua aides originally constructed the term quaatequia, "to pour water on someone's head," and Maya aides created variants of ok baa tu pol, "to put water on someone's head." The fact that much of the Nahuatl and Maya vocabulary for Catholic concepts either drew from indigenous antecedents and inspirations, or followed the pattern of describing the outer act of

10. Bernardino de Sahagún, Coloquios y doctrina Cristiana, ed. Migucl León-Portilla (México: Fundación de Investigaciones Sociales, Universidad Nacional Autónoma de México, 1986), p. 75.

11. Sell, "Friars, Nahuas, and Books," p. 120. See also Barry D. Sell, "The Classical age of Nahuatl Publications and Don Bartolomé de Alva's Confessionario of 1634," in A Guide to Confession Large and Swall, p. 28.

12. Lockhart, The Nahuas, p. 256; Louise Burkhart, "Doctrinal Aspects of Sahagún's Colloquios," in The Work of Bernardino de Sabagún: Pioneer Ethnographer of Sixteenth-Century Aztec Mexico, ed. J. Jorge Klor de Alva, H. B. Nicholson, and Eloise Quiñones Keber (Albany: State University of New York, Institute for Mesoamerican Studies, 1988), p. 68; Burkhart, The Slippery Earth, p. 39.

13. Burkhart, "Sahagún's Colloquios," pp. 65-82; Frances Karttunen and James Lockhart, eds., The Art of Nahuatl Speecb: The Bancroft Dialogues, UCLA Latin American Center Nahuatl Studies Series 2 (Los Angeles: UCLA Latin American Center Publications, 1987), p. 25.

14. Diccionario Maya, 4th ed. (México: Editorial Porrúa, 2001), p. 120; J. Eric S. Thompson, Maya History and Religion (Norman: University of Oklahoma Press, 1970), p. 204; "The Morley Manuscript, 1576 (?)," Laboratory of Anthropology, Museum of Indian Arts and Culture, Santa Fe, New Mexico, p. 151, as appears in Gretchen Whalen, "An Annotated Translation of a Colonial Yucatec Manuscript: On Religious and Cosmological Topics by a Native Author," (2003), http://www.famsi.org/reports/01017/index.html (accesscd November 4, 2006). 
Catholic concepts suggests that a significant portion of ecclesiastical vocabulary was probably created by Nahua and Maya aides, not friars.

Yet despite this large indigenous influence, the clergy also contributed to the formation of ecclesiastical texts. Indeed, in 1614 fray Martín de León claimed full responsibility for his published Nahuatl sermons stating explicitly that he "did not trust the Indians to make them." ${ }^{5}$ Despite León's personal declaration, most ecclesiastics contributed to their texts through a supervisory or editorial role to their native aides. When attempting to find indigenous counterparts for Catholic concepts, ecclesiastics (like their aides) commonly selected indigenous terms that appeared to run congruent to Christian ones. ${ }^{16}$ In some cases, the clergy purposefully used culturally- and religiously-charged indigenous terms within a Catholic context. In others, they were seemingly unaware or did not closely check the work of their native aides. Either way, ecclesiastics-at times knowingly, at times unknowingly-allowed religious texts to draw from preexisting frameworks and rhetoric to convey Catholicism. ${ }^{17}$

The lines distinguishing who contributed what to these texts remain blurred at best, especially when considering the prudence of omitting mention of native aides as religious authorities became increasingly wary of "indigenous influences" in ecclesiastical texts. Religious authorities were cognizant of the potential problems associated with translating Catholicism into indigenous languages. Indeed, due to the doctrinal errors ecclesiastics saw in the translation work of natives, the First Mexican Provincial Council of 1555 prohibited natives from translating sermons unless the sermons were given to knowledgeable natives and subsequently proofread by the friar or minister who gave it to them. ${ }^{18}$ Translated religious texts destined for publication had even more restrictions, and required the licenses and approvals of both secular and religious authorities. ${ }^{19}$ However, despite the increased suspicion surrounding the translation work of natives and the editorial rigors of publication, friars continued to use indigenous ghostwriters especially if the work was not destined for printing. ${ }^{20}$

15. Fray Martín de León, Primera parte del sermonario del tiempo de todo el año, duplicado, en lengua mexicana (México: Emprenta de la Viuda de Diego Lopez Daualos, 1614), preliminary page, unnumbered; translation mine.

16. Lockhart, The Nahuas, pp. 270-84.

17. For specific examples, see Burkhart's The Slippery Earth which covers the matter in detail.

18. Francisco Antonio Lorenzana, Concilios provinciales primero, y segundo, celebrados en la muy noble y muy leal ciudad de México, presidiendo el Illmo. Y Rmo. Señor D. Fr. Alonso de Muntúfar, en los años de 1555, y 1565 (México, 1769), pp. 143-3. See also Sell, "Friars, Nahuas, and Books," p. 122 note 20; Daniel Mosquera, "Nahuatl Catechistic Drama: New Translations, Old Preoccupations," in Nahuatl Theater, vol. 1, Death and Life in Colonial Nahua Mexico, ed. Barry D. Sell and Louise M. Burkhart, with a foreword by Miguel León-Portilla (Norman: University of Oklahoma Press, 2004), pp. 58-61.

19. Lorenzana, Concilios provinciales, p. 149; Sell, "Friars, Nahuas, and Books," pp. 58-9, 122.

20. Sell, "Friars, Nahuas, and Books," pp. 120-1. For a discussion on the degree of Spanish supervision and inspiration, see Lockhart, The Nahuas, pp. 402-3. 
Not only did natives write many ecclesiastical texts, they used many of them as well. To be sure, local priests employed religious tracts to help them fulfill their parochial duties in indigenous languages. Yet such duties, and such texts, largely fell under the purview of the community's head indigenous ecclesiastic steward generally called fiscales in Central Mexico and maestros in the Yucatan. Indeed, the regular and secular clergy often relied upon these indigenous stewards to aid them in their duties to baptize, administer to and bury the dead, celebrate feast days, and compose and deliver doctrinal discourses in their absence. ${ }^{21}$ For example, in the $1560 \mathrm{~s}$ Yucatan's bishop, Francisco del Toral, instructed the clergy that maestros could catechize, baptize the sick, administer extreme unction, and hear confessions from the sick and dying. ${ }^{22}$ These roles became amplified in peripheral towns, the pueblos de visita, that lacked a resident priest and oftentimes received very little ecclesiastical supervision. In understanding the essential role native stewards played in shaping multiple versions of colonial Catholicism, consider that in towns outside Mexico City in 1570 there was an average of one cleric for every 1,125 families. ${ }^{23}$ In Yucatan, at the apex of Franciscan influence, approximately 62 friars served 186 indigenous towns. ${ }^{24}$ And by the end of the colonial period, only approximately 37 percent of the 215 native towns in the Yucatan had resident priests. ${ }^{25}$

Thus, colonial realities made the clergy dependent on training indigenous aides not only in text production, but also as ecclesiastic stewards. Writing to Charles $\mathrm{V}$ in 1550, fray Rodrigo de la Cruz reported that since the friars in Ahuacatlanroughly 350 miles west of Mexico City-could only visit the neighboring towns infrequently, they gathered natives from the surrounding towns into newly formed schools to be instructed in religion, reading, and writing. After their instruction, the native pupils were to return home and repeat the catechism and religious teachings to others. ${ }^{26}$ Similar procedures occurred in the Yucatan during the early stages of the Franciscan's evangelization, and throughout the colonial period maestros were the only representatives of Christianity present in most Maya towns. ${ }^{27}$ This dearth of ecclesiastic presence in native communities inspired fray Pedro Beltrán de Santa Rosa to publish his novena stating the impossibility for Mayas to learn even the basic concepts of hell and glory "when they only have of these things a brief mention in a sermon that is perhaps preached to them each year." 28

21. For more on the duties of the fiscales see Ricard, The Spiritual Conquest, pp. 97-8; Lockhart, The Nahuas, pp. 210-15.

22. Anne C. Collins, "The Maestros Cantores in Yucatán" in Antbropology and History in Yucatán, ed. Grant D. Jones (Austin: University of Texas Press, 1977), p. 244.

23. Gibson, The Aztecs, p. 112.

24. Collins, "Macstros," p. 238.

25. Philip C. Thompson, Tekanto, A Maya Town in Colonial Yucatán (New Orleans: Middle American Research Institute, Tulane University, 1999), p. 17.

26. Ricard, The Spiritual Conquest, pp. 97-8.

27. Collins, "Macstros," p. 236.

28. Fray Pedro Beltrán de Santa Rosa, Nopena de cbristo crucificado con otro oraciones en lengua maya (Mćxico: don Francisco de Xavier Sanchez, 1740), photostat reproduction, preliminary page, unnumbered; translation mine. 
Although published ecclesiastical texts like Beltrán's emerged with the intent to lighten the burden of both priest and steward, many unpublished texts intended to assist local religious leaders also appeared. The works were small in size, brief, and typically housed between a makeshift leather cover making the text extremely portable and convenient for any priest or native steward burdened with the care of so many. These unpublished confessional manuals, books of sermons, catechisms, and so on lack both the lengthy prologues and the censorship of their published counterparts, and although their content occasionally strays a little off the "official" path of orthodoxy, it is not so far as to become doctrinally incorrect. In fact, although the orthography of most unpublished texts betrays native hands, the format and layout of such texts suggest the supervisory role of a priest familiar with such formulae, the use of a similar work as a template, or the native author's familiarity with the genre through religious training. For example, in a small leather cover no more than seven inches tall is a "libro de matrimonio de predicasiones de pariente." Penned in remarkably small Maya letters in the eighteenth century, each page betrays a skillful native hand whose perfect spelling of Spanish loanwords and use of Latin indicates either the supervision of an ecclesiastic, or a firm grasp on Spanish ecclesiastical texts. ${ }^{29}$

Surely in many cases unpublished texts and discourses ran more or less parallel to Catholic doctrine. Yet in others they did not. Due to their role in many communities as the only representative of Catholicism, indigenous stewards in many cases likely had ample opportunities not only to assist ecclesiastics compose religious texts, but also write some of their own. In the process, Nahuas and Mayas reinterpreted, composed, and recited religious discourses with little or no supervision to ensure orthodoxy. Indeed, in the 1570s friars Bernardino de Sahagún of Central Mexico and Diego de Landa of Yucatan both admitted to continually finding and confiscating handwritten sermons and religious tracts in which they had found things that displeased them. ${ }^{30} \mathrm{Had}$ such texts been submitted for publication, the above-mentioned editorial process would have rejected them outright. Yet these texts were not written for publication. Indigenous stewards typically wrote these texts to use in their own native communities. Illustrating the local origins and maintenance of such unpublished texts, Baltasar Mutul, the native notary of Teabo, composed a Maya text recounting the Passion of Christ which he titled "libro fassion" or passion book. Many years later, in 1875, the notary of Teabo used the remaining blank pages of the same book to record death records in Maya. ${ }^{31}$

29. "Maya Sermons," Garrett-Gates Mesoamerican Manuscripts Collection (C0744) no. 65, Department of Rare Books and Special Collections, Princeton University Library.

30. Louise M. Burkhart, Holy Wednesday, p. 165; René Acuña, "Escritos Mayas inéditos y publicados hasta 1578: testimonio del obispo Diego de Landa," Estudios de Cultura Maya 21 (2001), pp. 168-9.

31. "Discourses on the Passion of Christ and other Texts," Garrett-Gates Mesoamerican Manuscripts Collection (C0744) no. 66, Department of Rare Books and Special Collections, Princeton University Library. 
In short, three general categories of indigenous-language ecclesiastical texts exist. The first concerns published "official" texts written by ecclesiastic authors and/or their indigenous aides for a broad readership of both ecclesiastic and native populations. These texts experienced the most editorial scrutiny for unorthodoxy, and are more commonly found today due to the multiple printed copies of each text. The second category regards those unpublished, unofficial texts written by ecclesiastics and/or their native stewards for more local audiences including religious authorities. Likely patterned after existing models, these texts contained few examples of blatant unorthodox doctrine.

The third category of indigenous-language ecclesiastical texts concerns unpublished, unofficial texts written by natives for natives. Composed with minimal or no ecclesiastic supervision and avoiding the strict editorial process of publishing, these texts often crossed the boundaries of orthodoxy to present unofficial and unorthodox interpretations of Catholicism. The audience of these texts did not include the Spanish priest, but focused primarily on the local indigenous population..$^{32}$ To be sure, all indigenous-language religious texts contributed to Catholicism's varied interpretation. Yet this third category of texts largely represents those interpretations considered most unorthodox, and because these texts never experienced the multiple copies characteristic of publication, their locations and contributions to the evangelization of New Spain are less recognized. However, some manuscripts do exist to provide unique examples of unorthodox religious discourses. What such texts contained and how they conveyed their Catholic message and created multiple versions of Catholicism are questions to which this study now turns in its analysis of two unofficial religious texts, written by natives for natives, relating the conversion of Paul and the creation of Adam.

\section{The Conversion of Paul}

Penned over the space of eight folios of paper and amatl-figtree bark paper-in eloquent Nahua handwriting, the redaction of the conversion of Paul finds itself in a small, makeshift book sewn between two limp, vellum covers, one of which likely came from an old choirbook leaf. On the inside of the front cover are 64 profiles of Nahua heads arranged in eight-by-eight lines and drawn in black with some colored in blue-green, and pink. Although a recent scholarly work presented the text as "a translation of several chapters of the Acts of the Apostles dealing with the conversion of Saint Paul," my translation and analysis of the Nahuatl text proves otherwise

32. Some recent articles examining such texts are Timothy Knowlton, "Dynamics of Indigenous Language Ideologies in the Colonial Redaction of a Yucatec Maya Cosmological Text," Anthropological Linguistics 50:1 (Spring 2008); and David Eduardo Tavárez, "La idolatría letrada: un análisis comparativo de textos clandestinos rituales y devocionales en comunidades nahuas y zapotecas, 1613-1654," Historia Mexicana 49:2 (Oct.-Dec., 1999), pp. 197-252. 
(see Appendix). ${ }^{33}$ The work itself is a sermon with two topical themes; one concerning the conversion of Paul, the other regarding the ministry of Sebastian-neither are translations of biblical verse. My transcription and translation of the manuscript did not uncover its date, author, or provenance. ${ }^{34}$ However, philological examinations of its terminology and orthography made by both James Lockhart and myself suggest its creation sometime before 1560 by two distinct Nahua hands. ${ }^{35}$

According to the Nahuatl manuscript, as Paul was traveling on horseback, God struck his horse causing Paul's body to crumble and turn to dust. As demons collected his body-turned-dust in a cloak, Paul found himself in heaven and facing God. God questioned Paul as to why he killed Sebastian who righteously built holy temples and swept the roads that lead to heaven. After lecturing Paul on the privileged position of the poor and meek who in heaven receive golden seats and houses, God commanded his angels to take Paul to hell to witness the torments imposed on sinners. Among the fire and smoke that "reeks badly," Paul stood on hot coals for what seemed like twenty years, and witnessed devils and demons use iron tongs to cut up sinners and place their bodies in metal tubs. As he sobbed at the scene before him, the angels told Paul to no longer venerate his gods, before whom he had bled himself and cut his ears.

Muttering the phrase, "Jesus, Jesus, Jesus," Paul regained consciousness startling his companions who were keeping his body-turned-dust in a cloak. After reassuring his followers that he was neither a bad omen nor something monstrous, Paul informed them that their killing of Sebastian was a sin and that they should retrieve Sebastian's body from where they had executed him with arrows. Upon arriving at Sebastian's body, however, Paul's followers found Sebastian alive and unharmeda miracle ascribed to the angels of God-and led him to Paul's home.

When Sebastian arrived, Paul greeted him with the story of his journey to hell. Immediately following the tale, Paul gathered all his idols, burned them in the patio, and asked to be baptized. Sebastian refused arguing that Paul was to be bap-

33. Jaime Lara, Christian Texts for Aztecs: Art and Liturgy in Colonial Mexico (Notre Dame: University of Notre Dame Press, 2008), pp. 56-7.

34. Don Lorenzo Boturini Benaducci originally owned the manuscript which fell into the hands of Ramón Mena who later gave it to the father of Federico Gómez de Orozco. In 1945 Mexico's Musco Nacional acquired the manuscript, but Horcasitas noted its absence in his 1974 El teatro nábuatl. Today, the manuscript is housed in the Schøyen Collection as MS 1692, The Schøyen Collection, Oslo and London. See Horcasitas, El teatro nábuatl, pp. 447-59, 6103; Federico Gómez de Orozco: Catalogo de la colección de manuseritos relativos a la historia de América (México: Secretaria de Relaciones Extcriores, 1927), pp. 156-158; and John Glass, “A Census of Native Middle American Pictorial Manuscripts," in Guide to Ethnohistorical Saurces, vol. 14 of HMAI, ed. Robert Wauchope (Austin: Universiry of Texas Press, 1975), p. 175, no. 236.

35. Personal correspondenec with James Lockhart, December 13, 2007. A more detailed analysis of the manuscript appears in my forthcoming dissertation. A transcription and loose Spanish translation of the text by Galicia Chimalpopoca first appeared in Horcasitas' El teatro náhuatl, pp. 449-58. While similarities exist, my transcription of the original manuscript varies, at times markedly, from that found in Horcasitas' work; mine is the first English translation. 
tized by one named Peter who lived far away. Upon Sebastian's request, Peter came to Paul's house where-similar to Sebastian-he was greeted with the narrative of Paul's journey to hell. After hearing the story, Peter baptized Paul, changed his name from "Paul" to "Pablo" (Paul), and taught him how to read, write, pray, and live respectfully on earth.

To conclude, the text uses the first person voice to explain why natives should venerate and pray to Saint Paul, who, after all, is similar to them. The text states,

[W]e all will earnestly pray to our father Saint Paul. The reason that we will earnestly pray to him is that he believed afterward, and with us too it was after we believed that we burned the evil demons we had taken to be gods. We are not alone or the only ones who have done it this way; for our father Saint Paul did it the same way, for which reason we will earnestly pray on his feast day to our lord. Also, he [Paul] will pray to our lord God for us; that is all of the statement; it is to be observed well. ${ }^{36}$

The conditions under which the manuscript was created are ambiguous and offer a variety of plausible possibilities. Nahua aides could have copied the text from another existing manuscript-which a philological analysis suggests-or penned the account as dictated by a friar. It is true that the text contains many obvious influences from indigenous culture, but this could be the result of a friar modifying his sermon to his audience. Yet the sermon's misspelling and confusion of names, and its unorthodox events makes this possibility less probable. It is hard to believe that a friar or priest would have knowingly allowed such glaring errors to be preached. Moreover, the sermon's conclusion in the first person voice associates the author with the idolatrous parishioners and their culture: "The reason that we will earnestly pray to him [Paul] is that he believed afterward, and with $u s$ too it was after $w e$ believed that we burned the evil demons we had taken to be gods. We are not alone or the only ones who have done it this way; for our father Saint Paul did it the same way" (emphasis mine).$^{37}$ It is unlikely a friar or priest would use such rhetoric.

Finally, the Nahua profiles on the inside front cover convincingly indicate the indigenous authorship of this small book. Each of the eight lines of profiles concludes with a larger head and a name sign. Federico Gómez de Orozco notes that the profiles resemble those on tribute censuses. He also comments that Nahua fiscales used similar lines of profiles to represent a native fold and their corresponding tutor or instructor. ${ }^{38}$ Believing the manuscript was a religious play, John Hubert

38. Orozco, Catalogo, pp. 157-8; Horcasitas, El teatro nábuatl, pp. 601-2. 
Cornyn posited that the heads represented the names of the actors. ${ }^{39}$ Yet the figures also resemble those seen in select pictorial catechisms, or testarians. ${ }^{40}$ Regardless of their meaning, the presence of such profiles in a manuscript written by, and/or intended for a priest's personal use seems unlikely.

More likely, Nahua fiscales or assistants, either under their own or an ecclesiastic's charge, penned this manuscript for their own personal, local use to recount the conversion of Paul in a way that would be familiar to a Nahua audience, endear Paul to them, and encourage them to end idolatrous practices. ${ }^{41}$ In the process, the authors used the names and stories of key Christian figures and intentionally, or unintentionally, conflated and rearranged them to relate a new, unorthodox, Nahua version of the account.

\section{The Creation of Adam}

The Maya account is a small excerpt of a larger, leather-bound unpublished codex that appears to have belonged to a Maya maestro. Bequeathed to the Museum of New Mexico by Sylvanus Morley, and recently translated by Gretchen Whalen, the codex, or "Morley Manuscript," contains a compilation of writings on a variety of Christian topics written in Yucatec Maya. The inscription "año 1576" appears below a heading on one of the pages and analysis of the manuscript indicates that the book is a late eighteenth-century copy of an earlier original likely penned in 1576. Moreover, Whalen notes that sections of the manuscript were translations from Las preguntas que el emperador bizo al infante Epitus, a 1540 publication later banned by the Inquisition in $1559 .{ }^{42}$ The provenance of the manuscript is unknown.

The Maya tract on the creation of Adam states that after discussing the matter, the Holy Trinity decided to make an Earthly Paradise where God's creations could reside. In the center of this paradise, God created the first tree of the world and made it the greatest of all his wondrous creations. In the midst of the tree was a spring from which poured very sweet water and at whose source was a chair for a ruler under the command of Jesus Christ. The commentary mentions that the spring is "really wondrous to be seen, the marvel, the delight of the garden." 43

39. Horcasitas, El teatro nábuatl, p. 603. Cornyn believed the manuscript to date from 1530 . He likely thought it was the same play he and Byron McAfee claimed was performed in the atrium of Mexico City's parish church in 1530 . John H. Cornyn and Byron McAfee, "Tlacahuapahualiztli (Bringing up Children)," Tlalocan I:4 (1944), p. 316.

40. I thank Elizabeth Boone for her aid in analyzing the profiles.

41. Burkhart notes a similar familiarization of Saint James in various psalms of Sahagun's Psalmodia; see Louise Burkhart, "The Amanuenses Have Appropriated the Text: Interpreting a Nahuatl Song of Santiago," in On the Translation of Natipe American Literatures, ed. Brian Swann (Washington and London: Smithsonian Institution Press, 1992), pp. 339-355.

42. Whalen, "An Annotated Translation."

43. "The Morley Manuscript," p. 195, as appears in Whalen, "An Annotated Translation." 
As the Holy Trinity stood in the middle of Earthly Paradise, they discussed among themselves their desire to make man in their own image. Retreating to the back of Earthly Paradise, they gathered from the very center of the earth the best earth anywhere called "Damascene," meaning from Damascus. God used the Damascene earth to mold Adam's body; a body that could not move, see, hear, or speak, and that lacked skin and hair. After creating the body of Adam, God blew into him the breath of life and commanded him to see. Immediately, Adam could see and his hair and skin began to appear, as well as his veins. Then, God spat into the palm of his hand and placed his saliva on Adam's mouth and ears to open both. The story concludes with Adam declaring that he will give thanks to God for creating his body and the earth. ${ }^{44}$

Although the work's 346 pages fail to mention their author, the orthography of the manuscript, its misspelling of common Spanish words, its confusion and conflation of various biblical events, and its command of Maya rhetoric strongly indicate a Maya author, likely a maestro serving as a school master teaching indigenous youth-a common duty of indigenous religious stewards. ${ }^{45}$ In fulfilling their duties to instruct the community in Catholicism, maestros oftentimes used locally-made handwritten books that couched Christian concepts within precontact history and tradition. The early seventeenth-century priest Pedro Sánchez de Aguilar mentions his confiscation of such books from maestros due to their erroneous depictions of the creation of the world according to Genesis. ${ }^{46}$ Diego López de Cogolludo's Historia similarly cites this event while providing another example. He claims that upon his arrival from Spain, he heard mention of a fray Juan Gutiérrez who had seen Maya cartapacios (notebooks). These related the creation of man as being made from earth, grass, or thin straw, and whose bones, flesh, beard, and hair were made from grass or straw mixed with earth. Cogolludo then states how many such examples of cartapacios surely exist. ${ }^{47}$ The Morley Manuscript is likely such a book modifying and editing the Genesis account to better accommodate Maya culture.

\section{Nahua and MaYa Catholicisms}

Although both tales represent biblical stories, distinct native traditions from two Mesoamerican cultures have influenced their retelling in unique ways. In the

44. Ibid., pp. 194-99.

45. Ricard, The Spiritual Conquest, p. 98.

46. Pedro Sanchez de Aguilar, Informe contra idolorum cultores del obispado de Yucatan, in El alma encantada: Anales del Museo Nacional de México, ed. Fernando Benítez (México: Instituto Nacional Indigenista/Fondo de Cultura Económica, 1987), p. 115. I thank Timothy Krowlton for informing me of this citation and for his comments on the matter. For more on the works of Maya maestros particularly concerning the creation see Timothy Knowlton, "Dialogism in the Language of Colonial Maya Creation Myths" (Ph.D. diss., Tulane University, 2004); and Knowlton, "Dynamics."

47. Diego López de Cogolludo, Historia de Tuscatán (Madrid: J. García Infanzón, 1688), pp. 192-93. 
Nahua account of the conversion of Paul, Sebastian's sweeping of the roads to heaven, the golden seats awarded to the meek, and the tendency for Paul's followers to fear him as a bad omen or something monstrous after his extraordinary restoration are but a few of the many indigenous characteristics that betray its Nahua origins. For the Nahuas, sweeping held the practical and spiritual significance of removing the unclean from public and private spaces. Nahua priests routinely swept the temples of their gods. ${ }^{48}$ This precontact practice continued in the colonial period as the duty of Nahua sacristans and stewards of Catholic churches. Moreover, when Nahua testators of the Toluca Valley bequeathed household saints in their testaments, they oftentimes included the request that the recipient sweep around the altar of the saint. In one instance, to ensure that his wife and children sweep for his saint, a testator requested that his brothers "yell at them to sweep." $\$ 9$ Here, Sebastian's service of sweeping the roads to heaven would have made perfect sense to Nahua listeners.

In addition, the reference to golden seats appeals to both the Nahuas' appreciation of gold, considering it the "excrement of the gods" for its beauty, and their association of seated figures with rulers. ${ }^{50}$ Indeed, the phrase petlapan icpalpan nica, "I am on the reed mat, the seat," served as a metaphor for governing. ${ }^{51}$ The use of golden thrones as an image of power and privilege granted to the worthy surely resonated among Nahuas and was not uncommon as fray Pedro de Gante's 1553 Doctrina Christiana states how Christ will give the righteous golden thrones. ${ }^{52}$

Finally, Paul's plea for his followers not to take his sudden and miraculous restoration as a bad omen or something monstrous reflects the Nahua belief in anything frighteningly extraordinary or unexpected as portents of calamity. ${ }^{53}$ Sahagún recorded that someone who unexpectedly heard animal cries would either die or experience other misfortunes. ${ }^{54}$ Likewise, in Molina's Nahuatl/Spanish Confesionario mayor the priest asks the Nahua penitent, "Did you take as a bad omen the

48. For example, see Karttunen and Lockhart, The Bancroft Dialogues, p. 120. The Maya scem to have also appreciated sweeping for its spiritual significance as the ruler Mizcit Ahau swept the roads of Chichén Itzá, see Thompson, Maya Religion, p. 14. However, the act of sweeping appears much more frequently associated with the pre- and postcontact Nahua whereas such references for the Maya are scarce and typically refer to Mizcit Ahau and Chichén Itzá which, interestingly, is a settlement with Central Mexican influence.

49 Stephanie Wood, "Adopted Saints: Christian Images in Nahua Testaments in late Colonial Toluca," The Americas 47:3 (January 1991), p. 283.

50. For more on the symbolic significance of seats see Kevin Terraciano, The Mixtecs of Colonial Oaxaca: Nudzabui History, Sixteenth Through Eighteenth Centuries (Stanford: Stanford University Press, 2001), pp. 32-38.

51. Fray Alonso de Molina, Vocabulario en lengua castellana y mexicana, facsimile of $1571 \mathrm{~cd}$. (Madrid: Ediciones Cultura Hispánica, 1944), f. 81r.

52. Louise M. Burkhart, "Death and the Colonial Nahua," in Nabuatl Theater, vol. 1, Death and Life in Colonial Nabua Mexico, p. 40.

53. For more on omens, see Burkhart, The Slippery Earth, p. 64.

54. Fray Bernardino de Sahagún, Florentine Codex: General History of the Things of New Spain, book five, trans. and ed. Arthur J.O. Anderson and Charles E. Dibble, 13 parts (Santa Fe, New Mexico and Salt Lake City: School of American Research and University of Utah, 1953-82), pp. 151-56, passim. 
barn-owl, the owl, the weasel, the black beetle, the big, russet beetle, the skunk that made a stink in your home, ... or when your eyelids tremble, or you hiccup, or you sneeze? Perhaps you took as a bad omen the fire loudly crackling and exploding?"55

Overall, the Nahua sermon on the conversion of Paul employed precontact elements to create a mental performance in the minds of the listeners that would allow them to place an unfamiliar Catholic tale within a familiar cultural setting. Indeed, unlike a traditional sermon that resembles a lecture, and similar to precontact Mesoamerican traditions that employed oral discourse and imagery to accompany forms of writing, the Nahua sermon with its characters speaking and interacting with one another in Nahua-familiar ways truly would have allowed the listeners to think of Paul as a fellow Nahua and ex-idolater who would understand their struggling efforts to convert.

However, in the second tale concerning the creation of Adam, the discursive nature of the Trinity, Adam's lack of sight, speech, and hearing, the world tree, and the spring of water are key characteristics that betray its Maya origins. ${ }^{56}$ Similar to the actions of the Trinity, Maya creation myths typically include a group of deities that first discuss the creation of the earth and humans, and then perform such creations in a series of cycles. For example, a Maya creation myth recorded in the Chilam Balam of Chumayel states that before the creation of the world a group of individuals pondered the question, "How shall we make manifest and see man upon the road?"57 Moreover, Whalen comments how the Morley Manuscript resembles a passage in the Popol Vuh detailing how at the beginning of creation the deities Tepeu and Gucumatz "talked then, discussing and deliberating; they agreed, they united their words and their thoughts. $" 58$

Furthermore, the redaction of the creation of Adam seems to conflate various Maya myths that describe the creation of man as a series of processes starting with a sightless, speechless man made out of mud, and finishing with a man in possession of all his senses and faculties that could adequately venerate the gods. ${ }^{59}$ In the Chilam Balam of Chumayel the creators of the earth shaped man from moistened earth, but the humans lacked the ability to speak "for their organs of speech were

55. Molina, Confesionario mayor, f. 21 r; personal translation from the Nahuatl.

56. For more insights into the Maya influences on the Genesis account see Whalen's comments on the "Creation of Adam" in her "An Annotated Translation." Her preliminary work inspired much of my analysis on the Maya account.

57. Ralph L. Roys, "A Maya Account of the Creation," American Anthropologist, New Series, 22:4 (Oct. - Dec., 1920), p. 363. Also, see Munro S. Edmonson, trans. and ed., Heaven Born Mérida and Its Destiny: The Book of Chilam Balam of Chumayel (Austin: University of Texas Press, 1986), pp. 121-26.

58. Whalen, "An Annotated Translation."

59. The Nahua also believed that the carth and humanity were formed through a scries of creative cycles. See Miguel León-Portilla, Native Mesoamerican Spirituality: Ancient Myths, Discourses, Stories, Doctrines, Hymns, Pocms from the Aztec, Yucatec, Quiche-Maya and other Sacred Traditions, The Classics of Western Spirituality (New York: Paulist Press, 1980), p. 137. 
not yet opened." God then subsequently "said for speech to emerge." ${ }^{60}$ Moreover, the Popol Vuh details the progressive process by which man was formed ranging from mud-men to wooden effigies. Yet all such attempts were "merely an experiment, an attempt at people," for they "did not possess their hearts nor their minds; they did not remember their Framer, or their Shaper; they walked without purpose." ${ }^{\prime 1}$ Finally, the gods succeeded in their attempt at man creating from maize humans who, like Adam, would praise and venerate their creators. Certainly, then, a Maya listener of this tale on the creation of Adam could relate to a Trinity of deities discussing both the creation of the world and Adam who gradually obtained his human form and faculties to eventually praise his creator.

The tale's emphasis on the greatness of the first tree of the world situated in the middle of Paradise strongly resembles the world tree of the Maya. Seen inscribed throughout most pre-Columbian Maya sites, the world tree was a symbolic axis mundi rooted in the underworld, extending through the middleworld, and reaching the upperworld with its branches. ${ }^{62}$ For a Maya parishioner, it would seem only fitting that the world tree appear as the central, most grandiose creation in Earthly Paradise.

The placement of the ruler's seat at the source of the spring of water would also appeal to a Maya audience. Similar to Central Mexico, the Maya associated seated figures with rulers. Yet here, the account emphasizes not the seat but its location at the source of a spring. Devoid of many rivers, lakes, or streams, the Yucatec Maya survived their arid climate with the aid of cenotes, wells, and natural springs. ${ }^{63}$ Such natural water sources served as the cosmological center of many Maya settlements including Palenque, Dos Pilas, and Chichén Itzá. Moreover, water sources held religious significance as entrances to the underworld and the residences of deities, especially the chaaks or rain gods. The connection of these water sources to the "other world" also endowed them as sites of ancestor worship. ${ }^{64}$ Thus, seating a ruler at the source of a spring in the center of Paradise resonated theologically and spatially with Maya culture.

Finally, inserting a spring into the tale and describing it as the marvel and delight of the garden reflects Maya culture on a number of levels. Springs are rare in the

60. Edmonson, Chumayel, p. 125.

61. Allen J. Christenson, Popol Vub the Sacred Book of the Maya: The Great Classic of Central American Spirituality, Translated from the Original Maya Text (Norman: University of Oklahoma Press, 2007), p. 83.

62. David Carrasco, Religions of Mesoamerica: Cosmovision and Ceremonial Centers (San Francisco: Harper \& Row, 1990), pp. 98-103.

63. Cenotes are sinkholes containing groundwater.

64. Clifford T. Brown, "Caves, Karst, and Settlement at Mayapán, Yucatán," in In the Maw of the Earth Monster: Mesoamerican Ritual Cape Use, ed. James E. Brady and Keith M. Prufer (Austin: University of Texas Press, 2005), pp. 384-5. 
Yucatan making any such appearance a "marvel" and pleasant "delight." Also, the Maya considered water originating from springs as the most pure and without pollution, and water from the center of the source was especially coveted for ritual purposes. ${ }^{65}$ In a place termed "Paradise" where sin and misery had yet to enter, the purest water-spring water-would be the logical type found in the garden.

Overall, similar to the Nahua tale the Maya manuscript employs precontact traditions and culturally-specific elements to produce an oral discourse that would evoke a mental performance in the minds of the listeners, and that placed the foreign characters and events within a Maya setting. Indeed, one can imagine the maestro reading aloud the tale to a native audience that surely used the story's Maya-specific additions to make sense of the creation of Adam along familiar lines of thought. Speaking of the Nahua's evangelization, Burkhart states that "Christian teaching was effective only to the extent that it was compatible ... with preexisting belief and practice." 66 These two tales provide unique examples that both exemplify her statement, and extend its application to the Maya.

Yet despite whatever success the texts enjoyed in allowing Nahuas and Mayas to make sense of Catholicism on their own terms, the religious instruction both tales delivered was rife with unorthodox doctrine. Such unorthodoxy becomes apparent when juxtaposing the tales with their biblical originals. According to the biblical account of the conversion of Paul, as Saul-the man who held the cloaks of those who stoned the prophet Stephen-journeyed to Damascus to persecute the disciples of Christ, a bright light from heaven surrounded him and he heard the voice of Jesus. As a result, Saul lost his sight and his companions took him to Damascus. There, a man named Ananias blessed Saul and returned to him his sight after which Saul was baptized and began learning and preaching of Christ. In later chapters of the Bible, Saul is referred to as Paul, but although the exact moment this change took place is unclear, it did not happen at his baptism. ${ }^{67}$ Contrary to the Nahua version, then, in the biblical account Saul never goes to heaven to converse with God, never goes to hell to witness the torments of the wicked, never kills and subsequently meets with Sebastian, nor did Peter ever baptize Saul or change his name. Moreover, Saul never cut and bled his ears before his gods to venerate them, or owned a houseful of idols (see Table 1).

All such unorthodox elements originate from either of two sources. As seen above, the first derives from the tale's inclusion of Nahua-specific elements into the

65. Holley Moyes, "Cluster Concentrations, Boundary Markers, and Ritual Pathways: A GIS Analysis of Artifact Cluster Patterns at Actun Tunichil Muknal, Belize," in In the Maw of the Earth Monster, p. 287.

66. Burkhart, The Slippery Earth, p. 190.

67. Acts 9-10 (AV). Saul is continually referenced by his original name after his baptism. It is not until Acts $13: 9$ that he is referred to as Paul. 
TABLE 1

Comparisons between the Biblical and Nabua Accounts of the

Conversion of Paul

\section{Biblical Account}

Saul holds the cloaks of those that stone the prophet Stephen

Saul loses his sight

Saul goes to Damascus to receive his sight

Saul is baptized and learns the Christian doctrine

Saul begins to be referred to as Paul

\section{Nahua Account}

Paul and his followers shoot Sebastian with arrows

Paul is turned to dust

Paul goes to Heaven to converse with God

Paul goes to Hell

Paul's body miraculously regains its form

Paul and his followers retrieve Sebastian and take him to Paul's home

Paul burns his idols

Peter comes to Paul's home to baptize and instruct him in reading and writing

Peter changes Paul's name to Pablo

account. The second stems from misrepresentations of the biblical account. The Nahua tale's neglect to distinguish between the names "Saul" and "Paul" could be a simplification of the story's characters, or reflect the ambivalence of representing the unfamiliar " $s$ " syllable in Nahuatl, although generally speaking Nahuatl texts typically use " $\mathrm{x}$ " for "s." 68 Furthermore, the tale melds together two religious histories. Although Paul does (however passively) take part in the death of a Christian, it was Stephen not Sebastian. According to Catholic tradition, Sebastian was a Christian who lived hundreds of years later and was shot full of arrows by Roman soldiers at the end of the third century. When St. Irene of Rome went to retrieve Sebastian's body for burial, she found him alive and brought him to her house where he healed a blind girl. In the end, the Nahua tale employs elements from Sebastian's legend to create an unorthodox Nahua version of Paul's conversion that allows him to martyr, retrieve, and take Sebastian to his home where he meets Peter. The author(s) are either only superficially familiar with Sebastian's legend and Peter's biblical story, or simply disregard orthodoxy to create a place for both figures in their interpretation of Paul's conversion story.

68. Personal correspondence with James Lockhart, March 31, 2009. For more on the orthography of "s" see James Lockhart, Nahuatl as Written: Lessons in Older Written Nahuatl, with Copious Examples and Texts (Stanford: Stanford University Press, 2001), pp. 114-5. 
TABLE 2

Comparisons between the Biblical and Maya Accounts of the Creation of Adam

Biblical Account

God creates the Garden of Eden

God places the tree of life and the tree of knowledge of good and evil in the garden

God creates a river for the garden

God forms Adam from dust

God breathes into Adam's nostrils

Adam is cognizant and has control of his faculties

\section{Maya Account}

God creates Earthly Paradise

God places his greatest creation, the world's first tree, in the center of the garden

God creates a spring of sweet water and a chair for a ruler under the command of Jesus Christ

God forms Adam from Damascene earth

Adam cannot see, hear, or speak, and lacks skin and hair

God gives Adam his "breath," sight, hair, skin, and veins

God uses his saliva to open Adam's mouth and ears

Adam praises God for his creation

In the biblical account of the creation of Adam, God formed Adam from the dust of the ground, breathed into his nostrils and gave him life, and placed him in the Garden of Eden where in the midst stood both the tree of life and the tree of knowledge of good and evil. The garden also had a river. ${ }^{69}$ Although the phrase in Genesis 1:26 "let us make man" indicates a plurality to the creation, the Trinity never discusses at length Adam's creation, nor do they use earth from Damascus to create him. After its creation, Adam's body does not lack skin, hair, or the ability to see, hear, or speak. The world's first tree is not planted in the garden, nor is it God's greatest creation, and although the biblical account mentions a river that flows through the garden, the river does not originate from a spring in the midst of the first tree of the world, nor is there a chair for a ruler at the source of the river (see Table 2).

Similar to the Nahua account, then, the unorthodoxy in the Maya tale stems from both cultural adaptations and misrepresentations of the biblical account. The Morley Manuscript appropriated common biblical names, such as Christ and Damascus, and included them in the tale. Although the use of Christ to add clout to story is understandable, the purpose of using Damascene earth remains puzzling as

69. Although Genesis 1:26-31 and 2:1-11 present distinct accounts of the Creation, both combine to form the standard Christian narrative. 
the ancient city holds no real biblical significance other than as the birthplace of Eliezer, Abraham's steward, the residence of Naaman the Syrian who Elisha cured of leprosy, and as part of the history of Paul. ${ }^{70}$ The Maya account also melds biblical accounts together in its redaction of the Creation. For example, God spitting into the palm of his hand and using the spittle to unstop Adam's mouth and ears strongly reflects the biblical accounts of Christ giving sight to a blind man and healing a deaf man by anointing both with his spittle. ${ }^{71}$

Truly these were unpublished, unofficial texts "destitute of legitimate authority and revision" written by natives, under little or no ecclesiastic supervision, for natives. Both tales not only betray their distinct Nahua and Maya influences, but also illustrate the possibility for ecclesiastical texts to contain heretical messages. For the authors of both tales, orthodoxy paled in comparison to conveying a message that appealed to the listener. Certainly for the Nahua author(s) the goal was to increase devotion to Paul and decrease idolatry, not give an accurate retelling of the biblical account. Similarly, the Maya author seems more preoccupied with familiarizing the creation of Adam and promoting man's veneration of God than providing a faithful translation of Genesis. Ultimately, these unofficial religious texts produced culturally-specific versions of Catholicism that strayed greatly off the straight path of orthodoxy the Fourth Provincial Council desperately wanted to preserve.

\section{ConClusion}

In his work The Conquest of Mexico, Serge Gruzinski briefly mentions "unauthorized" texts and how "we would give a good deal to discover examples of these works" for their potential insights into natives' interpretation of Christianity. ${ }^{72}$ Yet despite their promise and their likely role as a significant part of the Catholic message (or messages) Nahuas and Mayas heard, unpublished, unofficial indigenouslanguage ecclesiastical texts remain understudied. However, this study brings to light two unofficial texts that provide a rare glimpse into what surely was common practice regarding the religious instruction natives received, and allow for some general conclusions.

The simplified and generalized term of "Mexican Catholicism" fails to appreciate the diverse branches of Catholicism that emerged throughout Mesoamerica in response to local and cultural preferences. Contributing to and expanding the bur-

70. Genesis 15:2; 2 Kings: 5; Acts 9:1-27. I thank Stafford Poole for his insight on the matter.

71. Mark 7:34; Mark 8:22-6.

72. Serge Gruzinski, The Conquest of Mexico: The Incorporation of Indian Societies into the Western World, 16th18th Centuries, trans. Eileen Corrigan (Cambridge: Polity Press in association with Blackwell Publishers, 1993), p. 56. 
geoning historiography using indigenous-language ecclesiastical texts to reexamine "the Spiritual Conquest" and its monolithic portrayal of Catholicism, this article provides two unique examples of how distinct cultures and traditions joined with colonial realities to create discourses-and thus versions-of Catholicism that varied from the Valley of Mexico to the Yucatan.

Indeed, the training of indigenous elites in writing and in Christian doctrine, and the paucity of ecclesiastic supervision of native communities enabled what must have been an extensive corpus of unpublished, unofficial texts written by native stewards charged with the spiritual care of their towns. Such texts inserted cultural elements within Christian teachings to form unorthodox, culturally-specific versions of Catholicism that appealed to native listeners. The tales' use of cultural elements and rhetoric inspired mental performances that enabled Nahua and Maya parishioners to envision unfamiliar Catholic doctrine along familiar, yet unorthodox, lines of thought.

In short, the two accounts illustrate how unofficial texts could employ culturallyspecific beliefs to shape the discourses of Catholicism and how these discourses could vary in orthodoxy. Furthermore, the tales have implications for how scholars envision Maya and Nahua colonial Catholicism and offer a glimpse into the creation of diverse Mesoamerican Catholicisms that extend beyond a single Central Mexican model. In the end, each of the unpublished manuscripts discussed represents a different brand of Catholicism whose unorthodox doctrines allowed a Nahua Paul to kill a road-sweeping Christian prophet, and a Maya Adam to rule from a spring under the shade of the world tree.

Pennsylvania State University

MARK Z. Christensen

University Park, Pennsylvania 


\section{APPENDIX \\ Transcription and Translation of the Nabuatl Sermon Relating the Conversion of Paul ${ }^{73}$}

[1]

Niman : ye no tehua : motlatlallohua yn icauallo yn paul : quimonequilti : yn ĩ totecuiyo dios motlahuitec yn icauallo : yn̄ paul: Auh yn yehuatl : yn paul : yn inacayo niman xixitihuetz cenca : mochi tetextic : yn inacayo : ça quipepenque : tilmacon cotlallique ompa quitlallito yn itlacatecollo : hua cate : auh yn yehuatl: yn paul: niman: tlamellauh : yn ilhuicac: Auh yn oquimottilli : ynĩ totecuiyo : yn dios : ynĩ paul : quimolhuilli tleyca yn oticmicti : ỹ Sebastian : ca nechcaltia : Ihuan tlatlachpana : yn otlica yni ye hualcaquizque [sic]: y nochantzico : yn ilhuicatl itic : ca y niquĩlaocollia yn icnotlaca : y motollinia : y nopilhuan : yn quiyhiyohuia : yn quiçiahui : camo yehuãtin : y niquitlaocollia yn onca : ymaxca : yn onca yntlatqui yhuã yn miec yncal : ca ça yehuãtin : yn atle ỹcal : yn thalticpac : yn cenca : motollinia

In axcan pauli huel xitlachiye yn oncan: motlalliquihui : yn icnotlaca : ca nicpixtica : yn ipapaquilliz : ymnetlamachtilliz : yn innecuiltonalliz yn aquique : yn choca yn tlaocoya : yn elçiçihui : y mochipa nechtemotinemi : yn çẽnca nentlamatinemi : yn momanepanotinemi : y motlãquaquetza çãyehuatin : yncal yeç in : yn iz mani : calli : yn teocuitlacalli yehuãtin : ypan: motlalliquihui : yn teocuitlaycpalli Cayac : onca motlalliya yn imicpal : Auh yn axca : ca otitlamahuiçoco paul : cuix huel ticpohuan : yn ixquich onoc: yn cepaquilliztli : y netlamachtilliztli : Auh yn axcan : Ca otitlamahuiço oc ye xitlachiye : yn mictlã : ca cenca miec yn tletl : ceca : popoca yhuan y cenca yac yn poctli mitzpixtiazque : y nopillohuan : yn angellome : y nimañ ye
[1]

Then, along with the others Paul's horse was running; our lord God brought about that his horse was struck by lightning. And then Paul's body quickly crumbled greatly and all turned to dust. His demons just gathered it up and put it in a cloak. And then Paul went straight to heaven. And when our lord God saw Paul he said to him, "Why did you kill Sebastian for he builds temples for me and sweeps on the road by which they enter my home in heaven? I am merciful to my children, the poor or humble who are afflicted, who endure hardships and earn their way with effort. I am not merciful to those who have possessions, belongings, and many houses but to those without houses on earth who greatly suffer.

[2]

Now, Paul, really look where the humble come to settle. I am caring for the happiness, prosperity, riches of those who cry, are sad, sigh, who always go about seeking me, languishing greatly, joining their hands, who kneel down. This will be the house of them only; here are their houses, houses of gold; they will come to sit on golden seats, for no one else sits on their seats. And now that you have beheld it, Paul, can you count all that is here, the eternal happiness and prosperity? And now that you have seen it, look also at hell, for there is much fire and smoke there, and the smoke reeks badly. My children the angels will go along taking care of you. Then the 
[3]

Quihuican : y mictlan : yẽhuãtin yn ãgelosme : Auh yn yehuatl : yn paul : yn ontlachix : y mictlan : cenca momauhti : cenca : chocac : çan achitonca : yn ipa moquetz : yn tlexochtli : cenca : yuhqui ma : cenpohualxihuitl : yn ipan quima huel quĩtlacaytac : yn diaplosme yn tlatlacatecollo yn intetepozcal : ynic techcocotona : tepozapazco : contlallia yn tonacayo : cenmicac ayc tecehuia : yn tlahuelliloque cenca miyec yn quitac yn quimahuiçoto : yn paul: camo huel motequixtiz : camo huel mochi mitoz camo huel mochi tictenehuazque yn ixquich yn tlayhiyohuilliztli : Auh yn iquac yn omozcalli yn paul ca cenca : chocac : cenca : tlaocox : quilhuique

\section{[4]}

IN ANgellosme : paul : ximomauhtin : xiquimauhcayta yn tlatlacatecollo : yn tlahuellilóque. macacomo [sic] . xiquitlayecolti : macaocmo : xiquitlamanilli : xiquĩquixtin : yn otiquitlayecoltiaya yn otiquimoteotiaya : yn imixpan, timiçoya y no ymixpan timonacaztequia : yn tlahuelliloque : yn tlatlacatecollo : Auh yn iquac: yn ohualmozcalli: niman.n Expa yn quito JeSus JeSus JeSus : niman : mochintin : motlatlaque yn oncan : onoca : yn ocan : quipiyeya Auh yn inacayo : çan ye quitoque Aço totetzauh : yn tlatohuani : quen o no monenechico: tzeo ça oticpepẽque : yn inacayo Auh yn yehuatl : yn paul : quimilhui Ma hannechmotetzahuitin nachcahuane : xinechtotomacan
[3]

angels take him to hell. And Paul saw things in hell; he was very frightened and wept; he stood on the hot coals for only a short time, but it seemed to him like twenty years. He saw the semblance of the devils and demons with their iron tongs with which they cut us up; they place our bodies in metal tubs; the evil ones never give us relief in all eternity. Paul saw and beheld a great deal; all the torments cannot be expressed, cannot all be told, we cannot mention them all here. And when Paul came to, he greatly wept and was very sad.

\section{[4]}

The angels told Paul, "Be afraid, look upon the evil demons with fear! Serve them no longer, no longer make offerings to them, get rid of those whom you served and venerated as gods, before whom you bled yourself and also before whom you were cutting your ears, the evil demons." And when he had regained consciousness, three times he said, "Jesus, Jesus, Jesus." Then all those who were there, who had been keeping his body, asked themselves and said, "Is the ruler [Paul] a bad omen for us? And how is it that his body was collected and we gathered it up in bits?" But Paul told them, "Don't take me for something monstrous, my lords, let me loose. 
[5]

tleyn oniquitato tlen onicmahuiçoto yn axca : nemechnonotzaz [sic] : nemechilhuiz [sic] : yn onicmahuiçoto ca cenca : otitlatlacoque yn oticmictique yn itlaço : yn dios : camo yuhqui mochihuazquia : Ma xiqualanati : yn inacayo : yn SebaStiã ypampa yn onimica : Auh yn axcan : Oc nechmotlaocollia : yn totecuiyo : yn dios auh niman : canato. yn ompa : quimĩminque : yn SebaStian : auh yn oyaque : yn quimanillito yn SebaStian : Auh yn onyaque cenca hueca neçi yn itlanextiayatzin : yn itech oquimotlallili : yn totecuiyo yn dios : yn ithni niman : ye quitotoma yn inacayotzin : ca noçan iuhqui : amo yc miqui : cenca : pacticac : yeyca yn cenca : pacticac : yn quipalehuiya

[6]

Yn iangelohua : yn dios : quihualhuycaque : yn ichan paul : niman : quilhui Nopiltzintzine : oticmiyhiyohuilti oticmoçiahuilti : ca onihuia yn ilhuicac ca onicnotilito : yn totecuiyo : yn dios yhuan y mictlan : ca o no nitlachieto : ca mopampa : yn onihuiya : yn onitlamahuiçoto: Auh yn axcan : ma tlatlacã yn tiaplosme : y nochã cate yn tlahuelliloque : yn o yuh quito $\mathrm{i}: \mathrm{yn}$ paul: niman : ye quiquixtia yn oquimoteotiaya : ythualco quinhualtepeuhque : oncan quintlatique : quitlachinahuique : Auh yn iquac : yn otlatlaque : niman : ye quilhuiya yn paul yn yehuatl : y SebaStian : quilhui :
[5]

As to what I saw and beheld, now I will speak to you and tell you what I beheld; for we sinned greatly when we killed God's beloved, such a thing should not have been done. Go and bring back Sebastian's body; because of this I had died. But now our lord God still favors me." Then, they went to get Sebastian from where they had repeatedly shot arrows at him. And when they went and got Sebastian, from very far away there could be seen his light that our lord God in heaven placed upon him [Sebastian]. Then they loosened his body, it was still as though he had not died; he was still very sound; the reason he was very sound was that the angels of God helped him,

\section{[6]}

they brought him to Paul's home. Then he [Paul] said, "O my honored noble, greetings; I went to heaven and saw our lord God, and I also went to see things in hell. It was because of you that I went to behold things. And now, let the evil devils that are in my home be burned." This is what Paul said. They then removed those they had taken to be gods and cast them down in the patio and there they burned and scorched them. And when they had been burned, Paul told Sebastian, 
[7]

Nopiltzintzine : ScbaStiantze : canell otlatlaque : yn tiaplosme : ma mopaltzinco : xinechmoquatequillitzino : niman quilhui : camo nehuatl : yni nimitzquatequiz : ce tlacatl : yn mitzquatequiz : cenca hueca nemi : ma quinotzati ytoca pedro yn ohualla niman : ye quinonotza : yn paul : yn iuhqui : oquitato yn ilhuicac Auh y mictlan : niman : quiquatequi yn pedro yn yehuatl : yn paul : niman : quicuepilli : yn itoca : yehuatl : yc quiquatequi : yc quinotz: yn Pablo : Auh yn o yuh ma quiquatequilli niman : ye quimomachtilliaya : yn amatl : Amo huel cemilhuitl : yn quimomachti : yn amatl: çan ach îtoca :

[8]

I nepantla motlallico : yn tonatiuh : ye cuele tlacuillohua : yehuatl: mochi quicuillo yn ixquich : yn teochihuialoni yn ixquich : y neyxcuitilli : yn ixquich : ynic timauhcanemizque : yn tpc titlaca : yn timacehualtin : Auh yhuã : cenca : tictlatlauhtizque : yn tixquichtin : yn totatzin : yn Sa. Pablo yehyca : y cenca tictlatlauhtizque : yn çatepan : tlaneltocac : Auh yn tehuatin ca ça no tepan : yn otitlaneltocaque : yn otiquĩtlatique : yn otiqu îteotiaya : yn tlahuelliloque : yn tlatlacatecollo: camo çan toceltin Camo çaN iyoque : yn iuhqui : oticchiuque ca no yuhqui yn quichiuh : yn totatzin : yn Sa pabla [sic] : yehyca : yn cencan : tictlatlauhtizque : In ilhuitzin yn ipan

[9]

yn totecuiyo : ca no topampa : quimotlatlauhtilliz : yn totte ${ }^{\circ}$. d.s Ca ye yxquich yn tlatolli huel pielloz :
[7]

"O my honored noble Sebastian, since the devils have been burned, for your sake baptize me. Then, he [Sebastian] told him, "It is not I who is to baptize you; a person will baptize you who lives very far away; let them go call him; his name is Peter." When he had come, Paul related to him how it was when he went to see heaven and hell. Then Peter baptized Paul and he [Peter] changed his name; he baptized and called him Paul. After he had baptized him, he taught him reading and writing. It did not take a whole day to teach him, but just a short time.

\section{[8]}

By midday, he could already write; he wrote everything having to do with prayer and holy examples, and everything about how we people of the earth, we humans, are to live respectfully. And in addition, we all will earnestly pray to our father Saint Paul. The reason that we will earnestly pray to him is that he believed afterward, and with us too it was after we believed that we burned the evil demons we had taken to be gods. We are not alone or the only ones who have done it this way; for our father Saint Paul did it the same way, for which reason we will earnestly pray on his feast day to

[9]

our lord. Also, he [Paul] will pray to our lord God for us; that is all of the statement; it is to be observed well. 